\title{
Determining the proper sowing time for the mixture of Hungarian vetch and triticale under continental climate conditions
}

\section{Hakan KIR $^{1 *}$ (1)}

${ }^{1}$ Department of Field Crops, Faculty of Agriculture, Kirsehir Ahi Evran University, 40100, Kirsehir, Turkey. E-mail: hakankir@ahievran.edu.tr. ${ }^{*}$ Corresponding author.

ABSTRACT: The research was conducted to determine forage yield and some quality characteristics of Hungarian vetch + triticale mixture, sowed in five different times under rainfed conditions of Central Anatolia, Turkey. The mixture was sowed in the second, third and fourth week of October, and the first and the second week of November in 2017 and 2018. Depending on the sowing times, plant height (PH) of Hungarian vetch and triticale was between 46.7 and $59.4 \mathrm{~cm}$, and 85.9 and $93.4 \mathrm{~cm}$, respectively. Green forage yield (GFY) was between 1746.2 and $2059.4 \mathrm{~kg}$ $\mathrm{da}^{-1}$, dry matter yield (DMY) was between 541.0 and $707.6 \mathrm{~kg} \mathrm{da}^{-1}$, crude protein yield (CPY) was between 80.4 and $110.3 \mathrm{~kg} \mathrm{da}{ }^{-1}$, digestible dry matter yield (DDMY) was between 340.8 and $453.9 \mathrm{~kg} \mathrm{da}^{-1}$, acid detergent fiber (ADF) ratio was between 31.8 and $33.7 \%$, neutral detergent fiber (NDF) ratio was between 44.7 and 49.5\%, total digestible nutrient (TDN) was between 57.9 and $60.4 \%$ and relative feed value (RFV) was between 118.6 and 133.8. Sowing time had a significant effect $(P<0.05)$ on $P H$ of triticale, while it has a very significant effect $(P<0.01)$ on GFY, DMY, CPY, DDMY, NDF ratios and RFV. Delaying the sowing time caused a decrease in the GFY, DMY and quality of the mixture. Results revealed that the first week of October is the most appropriate sowing time to obtain high dry matter yield with high quality under continental climate conditions of the Central Anatolia.

Key words: Hungarian vetch, triticale, sowing time, yield, quality.

Determinação da época de semeadura adequada para a mistura de ervilhaca Húngara e triticale em condições climáticas continentais

RESUMO: A pesquisa foi conduzida para determinar a produção de forragem e algumas características de qualidade da mistura de ervilhaca húngara + triticale, semeada em cinco épocas diferentes em regime de sequeiro na região Central da Anatólia, Turquia. A mistura foi semeada na segunda, terceira e quarta semanas de outubro, e na primeira e segunda semanas de novembro de 2017 e 2018 . Dependendo da época de semeadura, a altura da planta $(P H)$ da ervilhaca e triticale húngara foi entre 46,7 e 59,4 cm e 85,9 e 93,4 cm, respectivamente. $O$ rendimento de forragem verde (GFY) ficou entre 1746,2 e 2059,4 $\mathrm{kg} \mathrm{da}^{-1}$, o rendimento de matéria seca (DMY) foi entre 541,0 e 707,6 kg da ${ }^{-1}$, o rendimento de proteina bruta (CPY) foi entre 80,4 e 110,3 $\mathrm{kg} \mathrm{da}^{-1}$, digestivel seco o rendimento de matéria (DDMY) estava entre 340,8 e 453,9 $\mathrm{kg}$ da ${ }^{-1}$, a proporção da fibra em detergente ácido (FDA) estava entre 31,8 e 33,7\%, a proporção da fibra em detergente neutro (FDN) estava entre 44,7 e 49,5\%, o nutriente digestivel total (NDT) era entre 57,9 e 60,4\% e o valor relativo da alimentação (RFV) foi entre 118,6 e 133,8. A época de semeadura teve um efeito significativo $(P<0,05)$ no $P H$ do triticale, enquanto teve um efeito muito significativo $(P<0,01)$ nas relações GFY, DMY, CPY, DDMY, FDN e RFV. O atraso na semeadura ocasionou diminuição no GFY, DMY e na qualidade da mistura. Os resultados revelaram que a primeira semana de outubro é a época de semeadura mais adequada para a obtenção de alta produtividade de matéria seca com alta qualidade nas condições climáticas continentais da Anatólia Central.

Palavras-chave: ervilhaca húngara, triticale, época de semeadura, rendimento, qualidade.

\section{INTRODUCTION}

Vetch species are naturally found in the vegetation of Turkey and are cultivated in almost all regions. However, weak stem structure of vetch species causes lying down and decreases the yield and quality of forage when support plants are not available (AKSOY \& NURSOY, 2010). Therefore, the mixture of vetch with a cereal companion is recommended to help vetch plants to climb and solve lying down problem and prevent from rotting during winter.
Hungarian vetch, which is a cool-season legume forage crop, is a drought-resistant plant and can survive in very harsh winters without being damaged by frost. Triticale is a hybrid of wheat and rye, and an alternative cereal developed for marginal areas and resistant to drought and cold. Previous studies indicated that higher yield and forage quality can be obtained by cultivation of vetch with cereals compared to pure cultivation of vetch species (LITHOURGIDIS et al., 2011; SEYDOSOGLU et al., 2020). However, 
the number of studies conducted in Central Anatolia is not sufficient to determine the appropriate sowing time of vetch and cereal mixtures. The sowing time along with the ecological conditions has a significant impact on growth environment not only during the first development period but also during the whole vegetation period (AKKAYA, 1994; YAKTUBAY \& ANLARSAL, 1998). CACAN and KARABULUT (2018) determined the effect of different sowing times on yield and yield characteristics of barley, wheat and triticale species in a continental climate (Bingol province of Turkey) conditions. The plant height of triticale ranged from 76.0 to $82.8 \mathrm{~cm}$, green forage yield was between 1725.6 and $4466.7 \mathrm{~kg} \mathrm{da}^{-1}$, dry matter yield was between 490.7 and $977.7 \mathrm{~kg} \mathrm{da}$ ${ }^{1}$, crude protein ratio was between 10.3 and $14.2 \%$, crude protein yield was between 50.5 and $139.1 \mathrm{~kg}$ $\mathrm{da}^{-1}$, ADF ratio was 32.4-36.0\%, NDF ratio was 54.2$60.6 \%$, DDM ratio was between 60.9 and $63.6 \%$ and RFV was between 93.4 and 108.6. TURNA and ERTUS (2017) reported that plant height of the Altınova-2002 Hungarian vetch variety, which was cultivated at different sowing times, was 49.3$68.3 \mathrm{~cm}$, green forage yield was $512.0-1798.3 \mathrm{~kg}$ $\mathrm{da}^{-1}$, and dry matter yield was $199.3-593.5 \mathrm{~kg} \mathrm{da}^{-1}$. The performances of early sowed crops were better compared to the late sowing crops (TURNA \& ERTUS, 2017; CACAN \& KARABULUT, 2018). This study aimed to determine the suitable sowing time for the $50 \%$ Hungarian vetch $+50 \%$ triticale mixture (KIR, 2014) sowed under continental climate conditions of Central Anatolia, Turkey.

\section{MATERIALS AND METHODS}

The research was carried out under continental climate conditions of Kırşehir province (1090 $\mathrm{m}$ altitude, $39^{\circ} 08{ }^{\prime} \mathrm{N}$ and $34^{\circ} 06^{\prime} \mathrm{D}$ ) during 2017-2018 and 2018-2019 the vegetation periods (Figure 1). Plant materials used in the study were Altınova-2002 Hungarian vetch (Vicia pannonnica Crantz) and Tatlicak-97 triticale (Xtriticosecale Wittmack) varieties. Soil $\mathrm{pH}$ in the experimental field was slightly alkaline (7.96) and electrical conductivity was $0.74 \mathrm{dS} \mathrm{m}^{-1}$, indicating no salinity. Organic matter content was low (1.09\%), and lime content was very high (35.29\%) (KARAMAN, 2012). Plant available phosphorus content was sufficient $\left(9.96 \mathrm{~kg} \mathrm{da}^{-1}\right)$ and the potassium content $(240.0 \mathrm{~kg}$ $\mathrm{da}^{-1}$ ) was very high (KARAMAN, 2012). Long-term mean total precipitation of Kırşehir province during the vegetation period (October-May) is $315.8 \mathrm{~mm}$, and the average monthly temperature value is $6.9^{\circ} \mathrm{C}$ (Table 1). The average temperature $\left(9.1^{\circ} \mathrm{C}\right)$ in the first vegetation period (2017-2018) was $1.0^{\circ} \mathrm{C}$ higher than the average temperature $\left(8.1^{\circ} \mathrm{C}\right)$ of the second vegetation period (2018-2019). The temperature values obtained in both growing periods were higher than the long-term average values. The precipitation $(365.1 \mathrm{~mm})$ in the first year was above the long-term

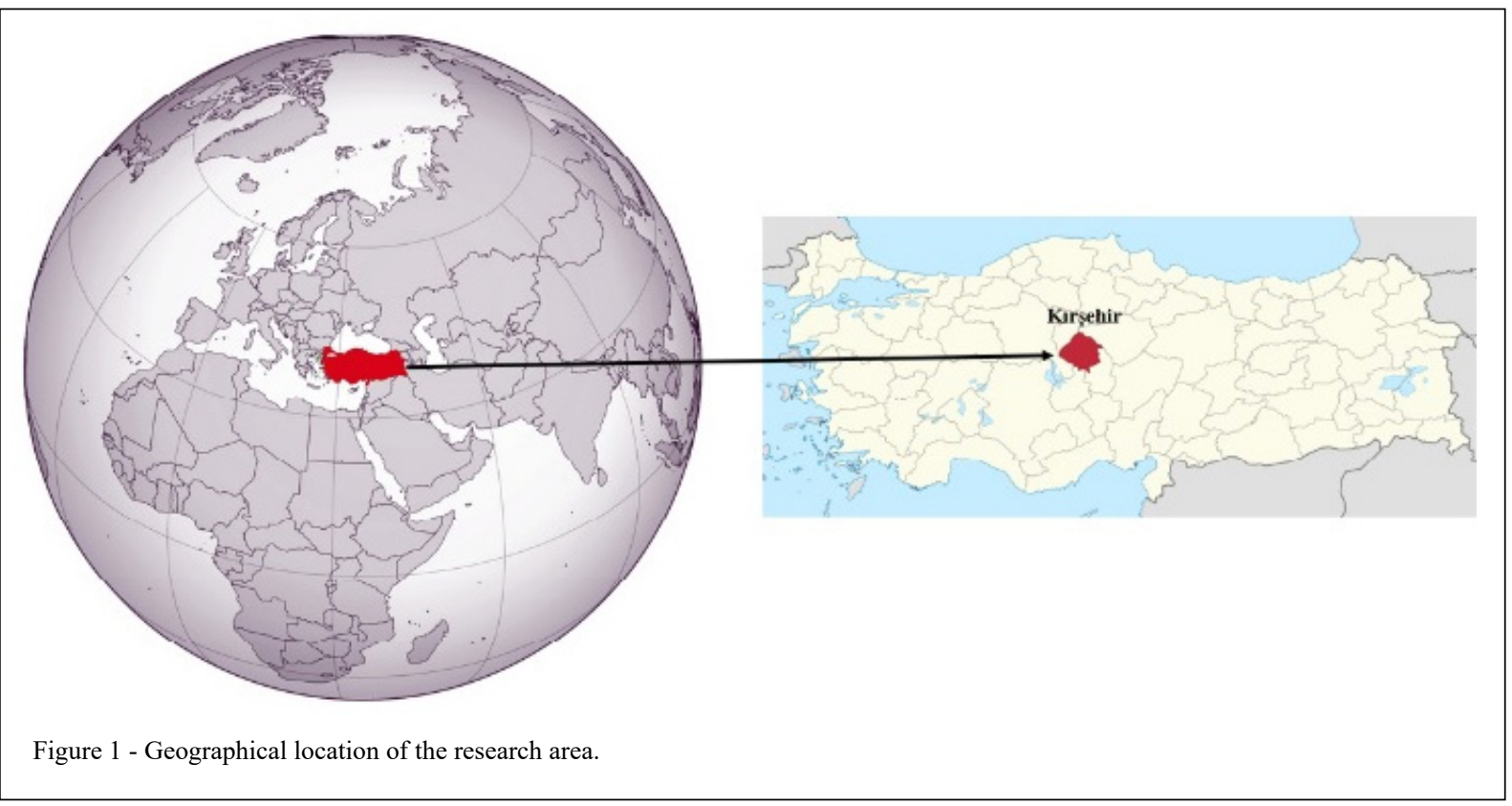

Ciência Rural, v.52, n.2, 2022. 
Table 1 - Monthly precipitation and mean air temperature during two growing seasons of the experiment.

\begin{tabular}{|c|c|c|c|c|c|c|}
\hline \multirow[t]{2}{*}{ Months } & \multicolumn{3}{|c|}{ 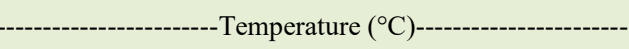 } & \multicolumn{3}{|c|}{-1 } \\
\hline & $2017-18$ & 2018-19 & Long-term average & $2017-18$ & 2018-19 & Long-term average \\
\hline October & 12.4 & 14.2 & 12.8 & 20.6 & 45.4 & 35.1 \\
\hline November & 6.3 & 8.1 & 6.4 & 56.0 & 21.1 & 37.2 \\
\hline December & 4.4 & 3.3 & 2.1 & 35.6 & 101.1 & 43.8 \\
\hline January & 2.1 & 0.9 & 0.4 & 74.3 & 42.2 & 42.7 \\
\hline February & 6.5 & 3.9 & 1.5 & 17.0 & 36.3 & 32.2 \\
\hline March & 9.7 & 6.5 & 5.6 & 87.7 & 10.2 & 35.7 \\
\hline April & 14.0 & 9.7 & 10.8 & 4.4 & 28.7 & 48.8 \\
\hline May & 17.3 & 18.1 & 15.9 & 69.5 & 16.5 & 40.3 \\
\hline Av./Total & 9.1 & 8.1 & 6.9 & 365.1 & 301.5 & 315.8 \\
\hline
\end{tabular}

average $(315.8 \mathrm{~mm})$, and the amount of precipitation in the second year $(301.5 \mathrm{~mm})$ was well below the long-term average (ANONYMOUS, 2020a) (Table 1). The average temperature and precipitation in the first year were higher than the second year of the study and long-term averages. In March, April and May of the first year, when the plants rapidly grown, total precipitation, was higher than the total precipitation occurred in the second year and long-term. The temperatures in March and April of the first year and in May of the second year were higher compared to the long-term averages (Table 1). The amount of seed used in pure sowing was 220 seeds $\mathrm{m}^{-2}$ for Hungarian vetch and 500 seeds $\mathrm{m}^{-2}$ for triticale, and the ratio of $50 \%$ Hungarian vetch (HV) $+50 \%$ Triticale (T) mixture have calculated based on this ratio (KIR, 2014; ONAL \& EGRITAS, 2017). The sowing times in the first and second years of the study were 2nd, 3 rd and 4th weeks of October, and the 1st and 2nd weeks of November. Seeds were sown manually with $20 \mathrm{~cm}$ row spacing. Each plot composed of 10 rows with $5 \mathrm{~m}$ long (ANONYMOUS, 2020b). The lay out of the experiment was randomized blocks with three replications. Fertilizer containing $4 \mathrm{~kg} \mathrm{da}^{-1}$ nitrogen $(\mathrm{N})$ and $7 \mathrm{~kg} \mathrm{da}^{-1}$ phosphorus $\left(\mathrm{P}_{2} \mathrm{O}_{5}\right)$ was applied before sowing (IPTAS, 1997). Since cereals become mature earlier, the harvest time was determined according to the cereals (KIR, 2014). Hungarian vetch was at the full flowering period when the triticale was at the flowering period, thus, the harvest was carried out in this period. One row from the edges and $50 \mathrm{~cm}$ from the beginning and end of the plots were considered as edge effect. The remaining area was harvested using a scythe. Harvested plants were weighed and green forage yields were calculated per decare. Five hundred grams of biomass harvested in each plot was dried at $60{ }^{\circ} \mathrm{C}$ until reaching a constant weight and dry matter yields were calculated (SLEUGH et al., 2000). The nitrogen content of the mixture was determined using Kjeldahl method and crude protein ratio was calculated by multiplying nitrogen content with the coefficient of 6.25 (AOAC, 2005). ADF and NDF contents were determined in the ANKOM200 Fiber analyzer (ANONYMOUS, 2020c). TDN ratio was calculated using the following equation given by HORROCKS and VALENTINE (1999);TDN $(\%)=(-1.291 \times \mathrm{ADF})+101.35$. DDM ratio was calculated by the equation introduced by SHEAFFER et al. (1995) using the ADF ratio. DDM ratio $=88.9$ - (0.779 x ADF \%). Digestible dry matter yield was calculated by multiplying the digestible dry matter ratio with dry matter yield. RFV was calculated using the following equation (ROHWEDER et al., 1978); $\mathrm{DMI}=(120 / \mathrm{NDF} \%) ; \mathrm{RFV}=$ Dry matter intake (DMI) X Digestible dry matter (DDM) /1.29. The data obtained were subjected to analysis of variance (ANOVA) using the MSTAT-C statistical package program. When ANOVA test indicated significant differences between the treatments, the mean values were compared with the LSD test at 5\% level of significance. (PETERSEN, 1994).

\section{RESULTS AND DISCUSSION}

\section{Plant height}

The effect of sowing times on plant height of Hungarian vetch plants was not statistically significant in the first year, while it was statistically significant $(\mathrm{P}<0.05)$ in the second year. Results of two-year combined data indicated that the effect of sowing time on plant height was statistically significant $(\mathrm{P}<0.01)$ (Table 2$)$. The effect of sowing 
Table 2 - Some yield and quality characteristics of different sowing times.

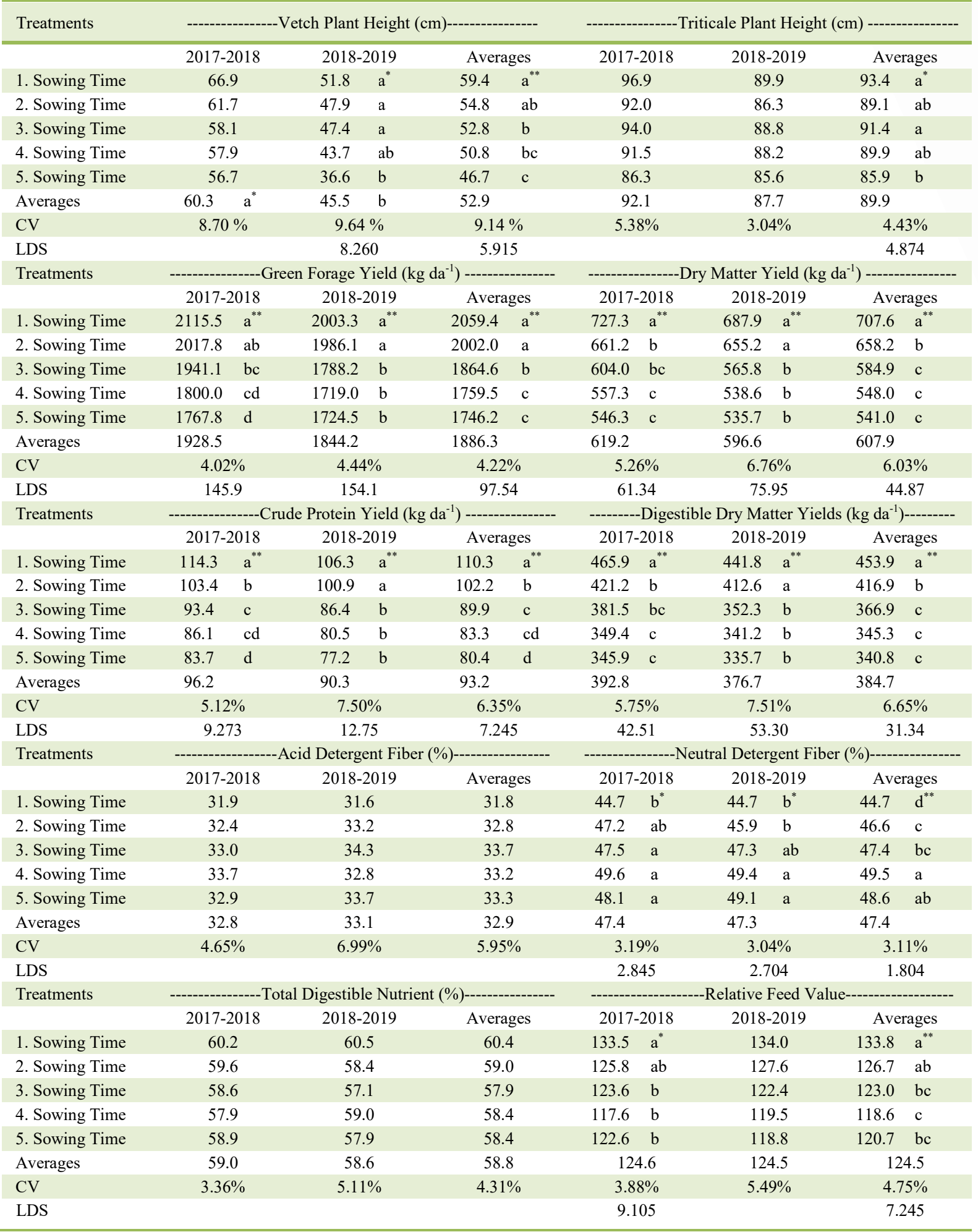

**: Differences between the averages followed by the same letter are not significant at $\mathrm{P}<0.01$ level.

*: Differences between the averages followed by the same letter are not significant at $\mathrm{P}<0.05$ level. 
time on plant height of triticale was not significant in the first and second years, while the sowing time caused a significant difference $(\mathrm{P}<0.05)$ in plant height according to two-year combined average plant height values (Table 2). The year had a significant effect $(\mathrm{P}<0.05)$ only on the plant height of Hungarian vetch. The plant height of Hungarian vetch in the two-year data varied between 46.7 and $59.4 \mathrm{~cm}$ and the triticale height was between 85.9 and $93.4 \mathrm{~cm}$. The results indicated that prolongation of vegetation period positively affected the plant height (Table 2). The highest plant height for Hungarian vetch and triticale was recorded in the first sowing time. Similarly, TEMEL and TAN (2002) stated that the plant height was shortened in late sowing. CACAN and KARABULUT (2018) reported that plant height of triticale varied between 76.0 and 82.8 $\mathrm{cm}$ in different sowing times. CACAN and KOKTEN (2017) who determined the appropriate sowing times of vetch varieties, reported that the plant height of Gorkem and Kralkızı vetch varieties was between 18.9 and $22.7 \mathrm{~cm}$, and 15.2 and $19.6 \mathrm{~cm}$, respectively. Both researchers recorded the highest plant heights in the first sowing times. The differences in plant heights can be attributed to the differences in ecological conditions of the experimental fields, and species and varieties used in the experiments.

\section{Green forage and dry matter yields}

The two-year combined data indicated that the effect of sowing times on green forage and dry matter yields was statistically very significant $(\mathrm{P}<0.01)$. The highest green forage yield $\left(2059.4 \mathrm{~kg} \mathrm{da}^{-1}\right)$ and dry matter yield $\left(707.6 \mathrm{~kg} \mathrm{da}^{-1}\right)$ were obtained at the first sowing time (Table 2). The green forage yield was high in the first and second sowing times, while the highest dry matter yield was obtained in the first sowing time (Table 2). Plants in winter sowing may have better root system and a longer vegetation period. Development of root system in the early sowing time causes better utilization of winter and spring rainfall. Sowing time significantly affects the green forage and dry matter yields by changing the yield factors such as the number of plants per unit area, the number of leaves, and plant height (GEREN \& ALAN, 2012). Therefore, higher green forage and dry matter yield in the early planting may be attributed to the higher number of days between the first sowing time and the harvest compared to the other sowing times. Results on high forage yield in early planting are in accordance with the findings reported by CACAN and KARABULUT (2018); COSKUN and CACAN (2019), who carried out studies with different species and varieties in similar ecologies.
Crude protein and digestible dry matter yield

The effects of sowing time on CP yield in both years and two-year averages were statistically significant $(P<0.01)$. Sowing time had a significant impact on the DDMY in the first $(\mathrm{P}<0.01)$, and second years $(\mathrm{P}<0.05)$ of the study. Similarly, the effect was significant $(\mathrm{P}<0.01)$ for two-year combined data (Table 2). The highest CPY (110.3 kg $\left.\mathrm{da}^{-1}\right)$ and DDMY (453.9 $\left.\mathrm{kg} \mathrm{da}^{-1}\right)$ were obtained at the first sowing time. The fourth and fifth sowing times placed in the low CPY and DDMY statistical groups. TEMEL and TAN (2002) stated that CP yield was affected by the sowing time, and late sowing caused a decrease in the CP yield. Negative correlation was reported between forage yield and protein ratio due to dilution of nitrogen in the increased volume of dry matter (Garcia del Moral et al. 1995). The CP and DDM yields are calculated based on DMY; therefore, the increase in CP and DDM yields were in agreement with the increase in DMY. TEMEL and TAN (2002) stated that DMY significantly decreased with delaying sowing time. The CP and DDM yields significantly decreased from the first sowing to the last sowing time. BINGOL et al. (2007)stated that the CP yields of $70 \%$ Hungarian vetch $+30 \%$ barley mixture in three different sowing times under Eastern Anatolian ecological conditions were $82.6,68.5$ and $33.2 \mathrm{~kg} \mathrm{da}^{-1}$, respectively, and DDM yields were 617.5, 429.5 and $258.5 \mathrm{~kg} \mathrm{da}^{-1}$, respectively. The CP yield of common vetch under Erzurum conditions in different sowing times ranged from 35.6 and $94.8 \mathrm{~kg} \mathrm{da}^{-1}$ (TEMEL $\&$ TAN, 2002). Similarities and differences between the findings of researchers may be attributed to the ecological conditions of the study areas and the species and varieties used in the experiments.

\section{$A D F$ and $N D F$ ratios}

Results of both years and two-year combined data indicated that the effect of sowing time on ADF ratio was not statistically significant. However, the effect of sowing time on NDF ratio was statistically significant $(\mathrm{P}<0.05)$ in the first and second years of the study. The effect of sowing time was very significant $(\mathrm{P}<0.01)$ in two-year combined data (Table 2). The ADF ratio in twoyear data varied between 31.8 and $33.7 \%$, and NDF ratio varied between 44.7 and $49.5 \%$. The lowest NDF ratio was obtained in the first sowing time $(44.7 \%)$, while, the highest NDF ratio was obtained in the fourth $(49.5 \%)$ and fifth $(48.6 \%)$ sowing times (Table 2). The NDF ratio had an increasing trend from the first sowing to the fifth sowing time. The $\mathrm{ADF}$ and NDF are the compounds that make up the 
plant cell wall. Therefore, high ADF and NDF ratios in the late sowing time may be associated to rapid growth in the short vegetation period and increase in ADF and NDF ratios. High ratios of ADF and NDF reduced the digestion of feed, thus, low ADF and NDF ratios are desired for better digestion of feed (GUNEY et al., 2016). The results revealed that differences in sowing time caused a significant change in forage quality as well as in forage yield. Studies conducted to determine the most suitable sowing times using different species and varieties showed that ADF and NDF ratios of triticale ranged from 32.4 to $36.0 \%$, and from 54.2 to $60.6 \%$, respectively (CACAN \& KARABULUT, 2018). The NDF ratio of hairy vetch was between 43.2-52.1\% (COSKUN \& CACAN, 2019); the NDF ratio of the Gorkem vetch variety was between $31.6-39.6 \%$, and the NDF ratio of Kralkıı vetch variety was between $26.5-34.8 \%$ (CACAN \& KOKTEN, 2017). The differences in the ADF and NDF ratios reported can be explained by the differences in species and varieties used and ecologies of study areas.

\section{Total digestible nutrient and elative feed value}

The effect of sowing time on TDN was not statistically different. The effect of sowing times on RFV was statistically significant $(\mathrm{P}<$ 0.05 ) in the first year, while it was not statistically significant in the second year. Results of twoyear combined data indicated that the effect was statistically very significant $(\mathrm{P}<0.01)$ (Table 2). Mean TDN in two-year data varied between 57.9$60.4 \%$ and RFV varied between 118.6 and 133.6 (Table 2). The differences in sowing time affected the RFV, and late sowing caused a decrease in the RFV. The TDN is composed of digestible cellulose and represents animal performance. The RFV reveals significant information on feeding factors such as feed consumption and digestibility, and is important to compare forage mixtures (GUNEY et al., 2016). The RFV is calculated from ADF and NDF values; thus, ADF and NDF values negatively correlate with the RFV value (LINN \& MARTIN, 1989; CINAR et al., 2019). Accordingly, low ADF ratio in the first sowing caused to obtain a high RFV. The RFV of triticale recorded at four different sowing times was between 93.4 and 108.6 (CACAN \& KARABULUT, 2018), and the RFV of mixtures of hairy vetch and different cereal species was between 104.6 and 129.8 (COSKUN \& CACAN, 2019). The differences in RFV values reported are related to the use of different species and the higher RFV values of legumes compared to grains.

\section{CONCLUSION}

The yield and some quality characteristics of the winter-grown 50\% Hungary vetch $+50 \%$ triticale mixture in different sowing times under ecological conditions of Central Anatolia, Kırşehir province, was significantly different. Early sowing had a positive effect on forage yield and quality, while delaying the sowing time negatively affected the yield and quality. Therefore, $50 \%$ Hungary vetch $+50 \%$ triticale mixture should be sowed in the first week of October under continental climate conditions of Central Anatolia and similar ecologies.

\section{DECLARATION OF CONFLICT OF INTEREST}

The authors declare no conflict of interest. The founding sponsors had no role in the design of the study; in the collection, analyses, or interpretation of data; in the writing of the manuscript, and in the decision to publish the results.

\section{ACKNOWLEDGEMENTS}

No funding was obtained to carry out this research from an individual or organization.

\section{AUTHORS' CONTRIBUTIONS}

The entire article was written by one author.

\section{REFERENCES}

AKKAYA, A. Wheat breading. Kahramanmaraş Sütçü Imam University, General Publication No:1, Textbooks Publication No: 1, (in Turkish), 1994. 225p.

AKSOY, I.; H. NURSOY. Determination of the varying of vegetation harvested Hungarian vetch and wheat mixture on nutrient content, degradation kinetics, in vitro digestibility and relative feed value. Journal of the Faculty of Veterinary Medicine, Kafkas University v.16, n.6, p.925-931. 2010. Available from: < http:// vetdergi.kafkas.edu.tr/extdocs/2010_6/925_931.pdf>. Accessed: Mar. 02, 2019. doi: $10.9775 / \mathrm{kvfd} .2010 .1932$.

ANONYMOUS. Climate Data, Turkish Republic Ministry of Agriculture and Forestry, General Directorate of Meteorology (in Turkish), 2020a. Available from: <https://www.mgm.gov.tr/iklim/ iklim-raporlari.aspx>. Accessed: Jan. 15. 2020.

ANONYMOUS. Triticale (XTriticosecale Witt.) technical guides, cool climate cereals (in Turkish) 2020b. Available from: $<\mathrm{https}: / / \mathrm{www}$. tarimorman.gov.tr/BUGEM/TTSM/Belgeler>. Accessed: Sept. 22, 2020.

ANONYMOUS. Analytical methods fiber analyzer A200. 2020c. Available from: <https://www.ankom.com/analyticalmethods-support/fiber-analyzer-a200>. Accessed: Feb. 18, 2020.

AOAC. Official methods of analysis of AOAC International. In . Animal Feed. 18th ed. Arlington, VA, USA: AOAC International, 2005. p.1-68.

Ciência Rural, v.52, n.2, 2022. 
BINGOL, N. T., et al. The effects of planting time and combination on the nutrient composition and digestible dry matter yield of four mixtures of vetch varieties intercropped with barley. Turkish Journal of Veterinary and Animal Sciences, v.31, n.5, p.297-302. 2007 Available from: <https://journals.tubitak.gov.tr/veterinary/issues/vet07-31-5/vet-31-5-3-0604-30.pdf>. Accessed: Feb. 17, 2018.

CACAN, E.; D. KARABULUT. Comparison in terms of the herbage yield and quality of some cereal species grown at different sowing time. Alınteri Journal of Agriculture Sciences, v.33, n.2, p.125-131. 2018. Available from: <https://dergipark.org.tr/ tr/download/article-file/611395>. Accessed: May, 10, 2019. doi: 10.28955/alinterizbd.360031.

CACAN, E.; K. KOKTEN. Determination of optimum sowing date for common and Narbonne vetch cultivars in Bingöl conditions. Turkish Journal of Nature and Science, v.6, n.1, p.19-23. 2017. Available from: <https://dergipark.org.tr/en/download/articlefile/347496>. Accessed: May, 10, 2019.

CINAR, S., et al. Effects of nitrogen fertilization rates on forage yield and quality of annual ryegrass (Lolium multiflorum L.) In Central Black Sea climatic zone in Turkey. Applied Ecology and Environmental Research, v.18, n.1, p.417-432. 2019. Available from: <http://www.aloki.hu/pdf/1801_417432.pdf $>$. Accessed: May, 10, 2020. doi: 10.15666/aeer/1801 417432.

COSKUN, N.; E. CACAN. The effect of sowing times on the yield and some quality characteristics in hairy vetch (Vicia villosa Roth.). SPEC International Agriculture and Rural Development Congress. Siirt 2019. Available from: $<$ https://www.researchgate net/publication/334510089 Tuylu Figde Vicia villosa Roth Ekim_Zamanlarinin_Bazi_Verim_ve_Kalite_Ozelliklerine Etkisi\#fullTextFileContent>. Accessed: May, 10, 2020.

GEREN,H.; O.ALAN. Effects of different sowing dates on the herbage yield and some other yield characteristics of two pea (Pisum sativum L.) cultivars. Journal of Aegean Agricultural Research Institute, v.22, n.22, p.37-47. 2012. Available from: <https://dergipark.org.tr/tr/ download/article-file/19891>. Accessed: May, 10, 2019.

GUNEY, M., et al. Relative feed value (RFV) and relative forage quality (RFQ) used in the classification of forage quality. Atatürk University Journal of Veterinary Sciences, v.11, n.2. 2016 Available from: <http://e-dergi.atauni.edu.tr/ataunivbd/article/ view/5000205951/5000175423>. Accessed: Feb. 05, 2018.

HORROCKS, R. D.; J. F. VALENTINE. Harvested forages: Academic Press. 1999. 426p.

IPTAS, S. The effcet of row spacing and barley and triticale mixtyre rates nurse crop on the seed yield and yield characteristics of Hungarian vetch. Journal of Agricultural Faculty of Gaziosmanpasa University. v.1997, n.1, p.123-136 1997. Available from: <http://ziraatdergi.gop edu.tr/Makaleler/1133997284 123-136.pdf>. Accessed: Feb. 05, 2018.

KARAMAN, M. Plant Nutrition. Gubretas Guide Books Series, Ankara, 2012.1069p.

$\mathrm{KIR}, \mathrm{H}$. Effects of cutting time and mixture ratio on the forage yields and qualities of the mixtures of Hungarian vetch with some cereal species under Kirsehir conditions. 2014. Department of Field Crops, Gaziosmanpasa University, Graduate School of Natural and Applied Sciences, PhD Thesisi,Available from: $<$ https://tez.yok. gov.tr/UlusalTezMerkezi/TezGoster?key=48XPj7KKQhKUgntk UiKO3D3p6bM7sfR7QmbSYjUiVqO6T8DNaEshF1PKYB R9W27Q>. Accessed: Feb. 05, 2018.
LINN, J. G.; N. P. MARTIN. Forage quality tests and interpretation: Minnesota Extension Service, University of Minnesota. 1989. 962p.

LITHOURGIDIS, A. S., et al. Dry matter yield, nitrogen content, and competition in pea-cereal intercropping systems. European Journal of Agronomy, v.34, n.4, p.287-294. 2011. Available from: <https:// www.sciencedirect.com/science/article/pii/S1161030111000232>. Accessed: Feb. 05, 2018. doi: 10.1016/j.eja.2011.02.007.

ONAL, A. O.; O. EGRITAS. Determination of forage yield, some quality properties and competition in common vetch-cereal mixtures. Journal of Agricultural Sciences, v.23, n.2, p.242252. 2017. Available from: $<$ http://tarimbilimleri.agri.ankara.edu. tr/2017/23_2/10.makale.pdf $>$. Accessed: Feb. 05, 2018.

PETERSEN, R., G. Agricultural Field Experiments: Design and Analysis: CRC Press. 1994. 426p.

ROHWEDER, D. A., et al. Proposed hay grading standards based on laboratory analyses for evaluating quality. Journal Of Animal Science, v.47, n.3, p.747-759. 1978. Available from: <https:// academic.oup.com/crawlprevention/governor?content $=\% 2 \mathrm{fjas} \% 2 \mathrm{f}$ article $\% 2 \mathrm{f} 47 \% 2 \mathrm{f3} \% 2 \mathrm{f} 747-759 \% 2 \mathrm{f} 4698544>$. Accessed: May, 10, 2018. doi: $10.2527 /$ jas $1978.473747 x$.

SEYDOSOGLU, S., et al. Effects of mixture ratio and harvest periods on yield of forage pea and triticale mixtures. Adnan Menderes University Journal of the Faculty of Agriculture, v.17, n.1, p.9-13. 2020. Available from: <http://www.aloki.hu/pdf/1706 1326313271. pdf $>$. Accessed: Feb. 10, 2020. doi: 10.15666/aeer/1706_1326313271.

SHEAFFER, C., et al. Acid detergent fiber, neutral detergent fiber concentration and relative feed value. Standart Tests to Characterize Alfalfa Cultivars. Available from: $<$ https://www. naaic.org/stdtests/acidfiber.pdf $>$. Accessed: Mar. 15. 2015.

SLEUGH, B., et al. Binary legume-grass mixtures improve forage yield, quality, and seasonal distribution. Agronomy Journal, v.92, n.1, p.24-29. 2000. Available from: <https://acsess.onlinelibrary. wiley.com/doi/full/10.2134/agronj2000.92124x>. Accessed: Mar. 15. 2019. doi: 10.2134/agronj2000.92124x.

TEMEL, S.; M. TAN. A research on determination of seeding and cutting time in common vetch (Vicia sativa L.) under Erzurum conditions. Atatürk University Journal of Agricultural Faculty, v.33, n.4. 2002. Available from: <https://dergipark.org.tr/tr/ download/article-file/34388>. Accessed: Feb. 05, 2018.

TURNA, C.; M. M. ERTUS. Effect of hay yield of some varieties of vetch on different planting time. 3. rd International Congress of Agriculture and Environment Proceeding Book. Konya: 132-138 p.2017. Available from: <https://www.researchgate. net/publication/323143752_BAZI_FIG_CESITERINDE_ FARKLI_EKIM_ZAMANLARININ_OT_VERIMINE_ETKISI $>$. Accessed: May, 10, 2019.

YAKTUBAY, S.; M. ANLARSAL, E,. A research on the effect of different sowing and cutting times on yield and yield components of some common vetch ( $V$. sativa $L$.) and hairy vetch ( $V$. villosa Roth) and barley (Hordeum vulgare $\mathrm{L}$.) mixtures under Çukurova conditions. Cukurova Üniversty, Institute of Science, Field Crops Department-PhD Thesis, Adana. (in Turkish). 1998. Available from: <https://otomasyon.cu.edu. tr/makale/CUKUROVAKOSULLARINDAFARKLI.pdf $>$. Accessed: May, 10, 2019. 